\title{
Evaluation of Growth and Fruit Quality of Cucumber (Cucumis sativus L.) Irrigated with African Catfish Cultured Wastewater
}

\author{
${ }^{1}$ A.O. Akinwole, ${ }^{*}$ A.B. Dauda and ${ }^{1}$ E.B. Oyewole \\ ${ }^{1}$ Department of Aquaculture and Fisheries Management, University of Ibadan, Nigeria \\ 2.Department of Fisheries and Aquaculture \\ Federal University Dutsin-Ma, P.M.B. 5001 Dutsin-Ma, Katsina State, Nigeria \\ [Corresponding Author: E-mail: tdabak@gmail.com; D: 08062085120]
}

\section{ABSTRACT}

This paper reports findings of an experiment carried out in a greenhouse to evaluate the growth and fruits quality of cucumber grown in plots irrigated with African catfish cultured wastewater compared with those irrigated with ordinary well water. Six circular African catfish culture tanks and six cucumber planter boxes were used for this experiment, three each for the fish cum cucumber integrated system and the control system of cucumber irrigated with ordinary well water. The results of the research indicated that fish cultured wastewater had a better influence on the plant height, the number, length, and diameterof leaves, as well as the diameter and length of the fruits. Six experts, each independently assessed fruits from the two treatments for juiciness, sweetness, taste and crispiness. The fruits were assessed by experts who though were aware of the purpose of the evaluation, did not know the identity of fruits they were assessing. The fish effluent fertigated cucumber fruits had a higher mean score in juiciness, sweetness, taste and crispiness. Wastewater from the African catfish production system thus exhibits the potential for reuse in the production of cucumber plants as it had no negative effect on the organoleptic quality of cucumber fruit produced.

Keywords: Cucumis sativus, Fish, Growth, Yield, Wastewater.

\section{INTRODUCTION}

Integrated agriculture has been identified as one of the ecosystem-friendly agricultural systems (Walia and Kaur, 2013). In fish culture, it is called integrated aquaculture and it involves the use of waste from aquaculture especially, sludge and wastewater from fish culture system in plant production (Akinwole et al., 2014). While so many products and by-products from plant or animal production are also used in fish production. According to Akinwole et al. (2014), wastewater from fish culture systems can be used to improve soil fertility and enhance plant growth. Apart from being ecosystem friendly, it also ensures efficient management of water resources which is already becoming a scarce resource. Since water used in aquaculture is not consumed, the wastewater can be made available for crop production. The crop production system can also serve as a cleansing medium for fish wastewater through uptake of nutrients by the plants while the clean filtered water is reuse in fish culture as it is done in aquaponics (Timmons et al., 2002). The culture of plants with wastewater has been worked on by many researchers though with different types of wastewater. For intance, Abegunrin et al. (2013), used kitchen wastewater for irrigating soil to grow Cucumber (Cucumis sativus), Ghanbari et al.(2007) researched on effect of municipal wastewater irrigation on yield and quality of wheat and some soil properties, and Akinwole et al. (2015), studied the effect of wastewater from African catfish culture on growth performance of Okra (Abelmoschus esculentus) raised under combine culture systems. Cucumber (Cucumis sativus) belongs to the family Cucubitaceae and is one of the three most economically important cucurbits. Others are watermelon (Citrullus lanatus), and melon (Cucumis melo) (FAO, 2006). The total world production of Cucumber as at 2017 was 83, 753, 861 tonnes, with China 


\section{Nigerian Journal of Basic and Applied Science (December, 2019), 27(2): 95-100}

alone producing $77 \%$ of the world total $(688,824$, 643 tonnes) (FAO, 2018). Egypt is the highest producer of cucumber in Africa (591, 858 tonnes as of 2017) but the current production in Nigeria is not available. The yield is largely varied as this may be influenced by so many factors. However, Eifediyi and Remison (2010) reported a yield between 16, 237 and 43, $259 \mathrm{Kg} / \mathrm{ha}$ in Edo State, Nigeria. Chinatu et al., (2017) reported a yield between 40,178 and $63,66 \mathrm{Kg} / \mathrm{ha}$ in Abia state, Nigeria. It requires a warm climate and can only grow in greenhouses in cold countries (Gruda et al., 2017). The optimum day temperature requirement is $30^{\circ} \mathrm{C}$, and optimum night temperature is $18-21^{\circ} \mathrm{C}$. Cucumber needs a plentiful amount of water but waterlogging is not good for its growth. Low humidity causes loss of water because of its large leaf area. Also high humidity promotes the formation of downy mildew which is a fungus that first appears as tiny tan or bright pink speckles on the leaves (Gruda et al., 2017). The soil should be fertile, with good amount of organic matters, well-drained with a pH of 6.0-7.0. According to Ingestad (1972), C. sativus requires nitrogen, potassium, phosphorus, calcium and magnesium (in the proportion 1: 0.75: 0.13: 0.09: 0.09, respectively). It prefers nitrates as nitrogen source and highly sensitive to high concentrations of ammonia. The optimal concentration of nitrogen in the solution is 200 to $300 \mathrm{mg} / \mathrm{L}$. Cucumber can germinate in three days if temperatures are at optimum levels. Flowering starts 40-45 days after sowing. Male flowers develop earlier than female flowers. Fruits can be harvested 1-2 weeks after flowering (Wang et al., 2007). Though cucumber has been cultured successfully with wastewater from kitchen (Abegunrin et al. 2013). our search of literature did not reveal any work where Cucumber was cultured in integration with fish, where wastewater from fish culture was used for irrigating the cucumber plots. Also, most of the work on the use of wastewater for crop production was only done on the growth performance of the plant produced but no information was provided on the effect of wastewater on either the nutrient value or edibility characteristics of the plant produced. This research, therefore, examines the growth performance and sensory (organoleptic) quality of cucumber fruit produced from irrigation with wastewater from the African catfish culture system.

\section{MATERIALS AND METHODS}

The study was carried out in the teaching and research farm of the Department of Aquaculture and Fisheries Management, University of Ibadan, between August and November 2015.

Six circular tanks were used for this experiment, three for the treatment 1 (the fish cum cucumber integrated system) and three for the treatment 2 (control system without water reuse). The dimensions of the fish culture tanks were $22.5 \mathrm{~cm}$ in diameter, $29 \mathrm{~cm}$ in depth and water level of 15 $\mathrm{cm}$ was maintained in order to have $20 \mathrm{~L}$ of water in the tank throughout the experiment. Six wooden boxes filled partly with sandy loam soil were used as vegetable beds, each of them had a dimension of $1.0 \mathrm{~m}$ by $0.5 \mathrm{~m}$ by $0.5 \mathrm{~m}(\mathrm{~L} \times \mathrm{B} \times \mathrm{D})$. The whole experiment was carried out in a fabricated greenhouse. The planter box with irrigation water from treatment one was labeled $A$, while the one irrigated with freshwater was labeled $\mathrm{B}$, and each treatment was done in triplicates.

Culture water from the fish tank as described by Akinwole et al. (2016) was used to irrigate the planter box (box A) and during the same time an equal volume of freshwater was used to irrigate planter box B. Cucumber seeds were planted at a spacing of $20 \mathrm{~cm}$ by $25 \mathrm{~cm}$ at $1.5 \mathrm{~cm}$ depth and a total of 16 plants in each wooden bed. The watering was commenced two weeks after propagation and the plants were watered with 2 liters for the first two weeks in each planter box, 4 liters in the third week, 6 liters for fourth and fifth weeks and 8 liters for sixth and seventh weeks in each planter box.

Growing of the cucumber started a week after the fish culture had commenced in order to use the wastewater from the fish cultured tank for 
watering of the cucumber in plant $A$ while subsequent watering follows suit. Watering of the cucumber was done when the soil was completely devoid of moist and this was checked by sticking a long stick into the soil. Whenever it is dried, water was added slowly, until it started flowing out of the drainage hole at the sides of the wooden box. The leaves were staked at all corners of the box to protect the plants and also for easy climbing, the plants started climbing at three weeks. Manual weeding was done using hand to remove weeds in the boxes. The experiment was carried out for a period of eight weeks. Performance of the plants was measured using growth parameters and sensory (organoleptic) quality assessment. The growth parameters considered include; plant height $(\mathrm{cm})$, number of leaves, leaf length $(\mathrm{cm})$, leaf diameter $(\mathrm{cm})$, fruit length $(\mathrm{cm})$, fruit diameter $(\mathrm{cm})$ and fruit weight (g). Lengths, heights and diameters were measured using a flexible tape and the fruits were weighed using a sensitive scale, the number of leaves was assessed by a visual count of the green leaves. Cucumber fruits were harvested at maturity between 6 and 8 weeks after sowing. The cucumber quality assessment was done by selecting a taste panel from the Department which included 3 members of academic staff and 3 students. The selection was done based on their awareness with the fruit and they assessed the fruits without knowing their identity. The parameters measured to assess the quality were appearance, sweetness, crispness, juiciness, odour and taste.The assessment was done on the scale of 5 , with 1 indicating the least rank and 5 indicated the highest rank.

\section{STATISTICAL ANALYSIS}

The data obtained were analysed using descriptive statistics (mean and standard deviation), while independent sample t-test was used to test if the difference for the growth parameters measured was significant between the two treatments.

\section{RESULTS}

The results of the growth parameters of the cucumber produced are shown in Table 1, Plant height of $203.30 \pm 29.01 \mathrm{~cm}$ was recorded in fertigated plants and was significantly higher $(P<0.05)$ than $166.13 \pm 30.40 \mathrm{~cm}$ recorded in unfertigated plants. The number of leaves $(17.67 \pm 3.21)$ was also higher significantly in fertigated bed. Leaf length and leaf diameter $(19.57 \pm 1.01 \mathrm{~cm}$ and $21.27 \pm 1.97 \mathrm{~cm}$ respectively) were also higher in fertigated plants but not significantly different $(P>0.05)$ from that of the unfertigated plant $(18.93 \pm 1.10 \mathrm{~cm}$ and $20.57 \pm 2.06$ $\mathrm{cm}$, respectively).

Fertigated plants also had a higher length of fruit $(19.92 \pm 0.90 \mathrm{~cm})$ and diameter of fruit $(5.78 \pm 0.73$ $\mathrm{cm}$ ) but were not significantly different from $19.50 \pm 2.18 \mathrm{~cm}$ (length of fruit) and $5.53 \pm 0.76 \mathrm{~cm}$ (diameter of fruit) obtained in the un-fertigated plant. The weight of fruit in un-fertigated plants $(327.10 \pm 94.91 \mathrm{~g})$ was significantly higher $(P<0.05)$, than $317.02 \pm 69.33 \mathrm{~g}$ recorded in the fertigated plant. Cucumber yield of $139,488.80 \mathrm{Kg} / \mathrm{ha}$ was obtained in fertigated plant and was higher compared to $65,420.00 \mathrm{Kg} / \mathrm{ha}$ obtained in the un-fertigated plant.

As shown in Table 2, the appearance was better in fruits from the un-fertigated plant with a mean score of $3.67 \pm 0.29$ compared to $3.28 \pm 1.21$ from the fertigated plants. The colour was also better $3.83 \pm 0.29$ in fruits from un-fertigated plants as against $3.50 \pm 1.09$ of the one from fertigated plants. Sweetness in fruits from fertigated plants $(3.56 \pm 0.77)$ was better than fruits from unfertigated plants $(3.50 \pm 0.50)$, Crispness of $4.28 \pm 0.25$ was recorded in fruits from fertigated plants and it was higher than $3.83 \pm 0.76$ in unfertigated plants. Juiciness and taste were also higher in fruits from fertigated plants $(4.11 \pm 0.19$ and $4.28 \pm 0.54)$ than un-fertigated plants (3.83 \pm 0.29 and $3.67 \pm 1.04)$. However, $4.17 \pm 0.76$ recorded for the odour in fruits from the unfertigated plant was higher than $4.11 \pm 0.51$ recorded for fruits from fertigated plants Generally, the perceived quality score of $77.86 \pm 12.19 \%$ recorded in fruits from fertigated plants was higher than that of fruits from unfertigated plants $(75.42 \pm 13.94)$. 
Nigerian Journal of Basic and Applied Science (December, 2019), 27(2): 95-100

Table 1: Growth parameters of cucumber plants produced in fertigated and un-fertigated Plots

\begin{tabular}{lll}
\hline & \multicolumn{2}{c}{ TREATMENTS } \\
PARAMETERS & FERTIGATED & UN-FERTIGATED \\
\hline Plant height $(\mathrm{cm})$ & $203.30 \pm 29.01^{\mathrm{a}}$ & $166.13 \pm 30.40^{\mathrm{b}}$ \\
No of leaves & $17.67 \pm 3.21 \mathrm{a}$ & $15.33 \pm 3.21 \mathrm{~b}$ \\
Leaf length $(\mathrm{cm})$ & $19.57 \pm 1.01$ & $18.93 \pm 1.10$ \\
Leaf diameter $(\mathrm{cm})$ & $21.27 \pm 1.97$ & $20.57 \pm 2.06$ \\
Total number of fruits & 22 & 10 \\
Length of fruit $(\mathrm{cm})$ & $19.92 \pm 0.90$ & $19.50 \pm 2.18$ \\
Diameter of fruit $(\mathrm{cm})$ & $5.78 \pm 0.73$ & $5.53 \pm 0.76$ \\
Weight of fruit $(\mathrm{g})$ & $317.02 \pm 69.33^{\mathrm{b}}$ & $327.10 \pm 94.91^{\mathrm{a}}$ \\
Yield $(\mathrm{kg} / \mathrm{ha})$ & $139,488.80$ & $65,420.00$ \\
\hline
\end{tabular}

Different superscript on the mean $( \pm S D)$ along the row showed a significant difference $(P<0.05)$

Table 2: Mean score values of the sensory evaluation of harvested cucumber fruits produced with fertigated and unfertigated water

\begin{tabular}{lllllll}
\hline $\begin{array}{l}\text { SENSORY } \\
\text { PARAMETERS }\end{array}$ & \multicolumn{5}{c}{ TREATMENTS } \\
& \multicolumn{3}{c}{ FERTIGATED } \\
\hline & Mean scores & Min. & Max. & Mean scores & Min. & Max. \\
Appearance & $3.28 \pm 1.21$ & 2.50 & 4.67 & $3.67 \pm 0.29$ & 3.50 & 4.00 \\
Colour & $3.50 \pm 1.09$ & 2.50 & 4.67 & $3.83 \pm 0.29$ & 3.50 & 4.00 \\
Sweetness & $3.56 \pm 0.77$ & 2.67 & 4.00 & $3.50 \pm 0.50$ & 3.00 & 4.00 \\
Crispness & $4.28 \pm 0.25$ & 4.00 & 4.50 & $3.83 \pm 0.76$ & 3.00 & 4.50 \\
Juiciness & $4.11 \pm 0.19$ & 4.00 & 4.33 & $3.83 \pm 0.29$ & 3.50 & 4.00 \\
Odour & $4.11 \pm 0.51$ & 3.67 & 4.67 & $4.17 \pm 0.76$ & 3.50 & 5.00 \\
Taste & $4.28 \pm 0.54$ & 3.67 & 4.67 & $3.67 \pm 1.04$ & 2.50 & 4.50 \\
Overall score & $27.11 \pm 1.02$ & 20.00 & 33.00 & $26.50 \pm 2.29$ & 19.00 & 32.00 \\
Obtainable score & 35.00 & 35.00 & 35.00 & 35.00 & 35.00 & 35.00 \\
\% quality score & $77.86 \pm 12.19$ & 57.14 & 94.29 & $75.42 \pm 13.94$ & 54.29 & 91.43 \\
\hline
\end{tabular}

\section{DISCUSSION}

All the growth parameters were higher in fertigated plants except the weight of fruit. Better performance obtained in the fertigated plants may be associated with enrichment of soil with nutrients from aquaculture wastewater. This is in line with the position of Akinwole et al. (2014) who opined that wastewater from fish culture systems can be used to improve plant growth. Cimpeanu et al. (2013) reported that fertigation assures the entire necessary nutrients for the growth and fructification of cucumbers. Higher yield obtained in fertigated bed was also in consistent with the result of Ewulo et al. (2008) and Akinwole et al. (2015) who attributed increased growth of crop plants to the release of more nutrient elements which had been made available to the plant in the wastewater from the catfish production system. These findings were similar to the results of Hussain et al. (2001) who 
recorded an increase in cucumber growth and yield with an increase in sludge application. Similarly, Singh et al. (2011) also observed that wastewater has the potential to supply major nutrients (NPK) and micronutrients to support plant growth. Thus, cucumber plants fertigated with wastewater from the catfish culture system was able to yield more than the un-fertigated treatment as the wastewater served as a valuable source of nutrients and organic matter needed for maintaining fertility and productivity levels of the soil required for the optimum performance of the cucumber plant. Wastewater can have a positive effect on soil and eventually plant growth, due to its being rich in organic matter and nutrients (Ghanbari et al., 2007).

The results of the sensory (organoleptic) quality implied that use of wastewater from fish culture does not have negative impact on the quality of cucumber fruit produced, though no test was carried out on the nutrient value of the fruit produced. The sensory evaluation revealed that plants obtained from the fertigated bed were better in terms of sweetness, juiciness, crispness and taste. Though un-fertigated plants were better in terms of fruits' appearance, colour and odour, however, the general sensory quality score was better in plants from fertigation. However, the qualities that were better in fertigated plants were of more interest in terms of consumption than those that were better in unfertigated plants. The research further established the assertion of Akinwole et al. (2015) that wastewater from fish culture which would have constituted nuisance to the environment, can serve as source of irrigation for watering plants cultured along with them and also enhance the soil with nutrients needed to ensure better yield and possibly better quality as it is established in the findings of this research. This was an indication that fertigation had a better influence on consumption characteristics with respect to the edibility of the fruit. This could be as a result of higher mineral content in the wastewater used (Akinwole et al., 2016) in irrigating the fertigated plants (Kumar et al.,
2010), which could have resulted in higher mineral and nutrient content of the fruits thereby increasing the palatability and edibility of the fruit.

\section{CONCLUSION}

It can be established from our findings that, wastewater from African catfish production system has the potential of reuse in the production of cucumber plants as it enhances the growth of the plants and has no negative effect on the organoleptic quality of the fruit produced. It was found to improve the edibility characteristics of the cucumber plants. However, further studies are required in this area especially on the nutrient value of the plants produced from fertigation using wastewater from fish culture.

\section{REFERENCES}

Abegunrin, T. P., Awe G. O., Idowu D. O., Onigbogi, O. O. and Onofua, O. E. (2013). Effect of Kitchen Wastewater Irrigation on Soil Properties and Growth of Cucumber (Cucumis sativus). Journal of Soil Science and Environmental Management, 4(7): 39-145.

Akinwole, A.O., Dauda, A.B. and Nwolisa, E.C. (2014). Influence of Culture Water Drawoff on Growth of the African catfish (Clarias gariepinus, Burchell 1822) cultured under Integrated system. International Journal of Applied Agricultural and Apicultural Research (IJAAAR), 10: 139-144.

Akinwole, A.O., Dauda, A.B. and Nwolisa, E.C. (2015). Effect of wastewater from African catfish (Clarias gariepinus) on growth performance of okra (Abelmoschus esculentus) raised under combined culture system.In: Proceedings of th $30^{\text {th }}$ Annual conference of Fisheries Society of Nigeria held between $22^{\text {nd }}-27^{\text {th }}$ November at ETF lecture Theater, Delta State University, Asaba Campus, Asaba Delta State, Nigeria. Pp 668-670.

Akinwole, A.O., Dauda, A.B. and Oyewole E.B. (2016). Influence of partial and total static culture water withdrawal on water quality, 
growth and feed utilization of Clarias gariepinus juveniles. International Journal of Fisheries and Aquatic studies (IJFAS), $4(6): 175-178$.

Chinatu, L.N., Onwuchekwa-Henry, C.B. and Okoronkwo, C.M. (2017). Assessment of yield and yield components of cucumber (Cucumis sativus L.) in Southeastern Nigeria. International Journal of Agriculture and Earth Science, 3(1): $35-44$.

Cîmpeanu, G., Neata G., Teodorescu, R., Cîmpeanu, C., Folea, I. (2013). Influence of fertilization system on the quality of cucumbers. Notulae Botanicae, Horti Agrobotanici, Cluj-Napoca, 41(1): 226-230.

Eifediyi, E. K. and Remison, S.U. (2010). Growth and yield of cucumber (Cucumis sativus L.) as influenced by farmyard manure and inorganic fertilizer. Journal of Plant Breeding and Crop Science, 2(7): 216-220,

Ewulo, B. S., Ojeniyi, S. O. and Akanni, D. A. (2008). Effect of poultry manure on selected soil physical and chemical properties, growth, yield and nutrient status of tomato. African Journal of Agricultural Research. 3(9): 612-616.

FAO (2006). Food and Agriculture Organisation Statistics for cucumber www.faostat.fao.org/faostat/cucurbits, assessed 12th December, 2015.

FAO (2018). Food and Agriculture Organization Statistics FAOSTAT for crops, List of countires by cucumber production. http://www.fao.org/faostat/en/\#data/QC/ assessed 14th June 2019.

Ghanbari, A., Abedikoupai, J. and TaieSemiromi, J., (2007). Effect of municipal wastewater irrigation on yield and quality of wheat and some soil properties in sistan zone. Journal of Science and Technology of Agriculture and Natural Resources, 10: 59-74.

Gruda, N., Sallaku, G. and Balliu, A. (2017). Crop Technologies: Cucumber.Editors: W. Baudoin, A. Nersisyan, A. Shamilov, A. Hodder, D. Gutierrez, S. de Pascale, S. Nicola, N. Gruda, L. Urban, J. Tanny In: Good Agricultural Practices for Greenhouse vegetable production in the South East Europe Countries- Principles for sustainable intensification of smallholder farms. FAO Plant Production and Protection Paper 230, Rome Italy. Pp. 287-298

Hussain, I., Raschid-Sally, L., Hanjra, M. A., Marikar, F. and van der Hoek W. (2001). A framework for analyzing socioeconomic, health and environmental impacts of wastewater use in agriculture in developing countries. IWMI working paper 26. Colombo, Sri Lanka: International Water Management Institute.

Ingestad, T. (1972). Mineral nutrient requirements of cucumber seedlings. Plant Physiology, 52: $332-338$

Kumar, S., Dagnoko, S., Haougui, A., Ratnadass,A., Pasternak, D. and Kouame C. (2010). Okra (Abelmoschus spp.) in West and Central Africa: potential and progress on its improvement. African Journal of Agricultural Research, 5: 35903598

Singh, P.K., Deshbhratar, P.B. and Ramteke, D.S. (2011). Effects of sewage wastewater irrigation on soil properties, crop yield and environment. Agricultural Water Management, 103:100-104.

Timmons, M.B.,Ebeling, J.M., Wheaton, F.W.,Summerfelt, S.T. and Vinci B.J. (2002). Recirculating aquaculture systems, 2nd Edition. Northeast Regional Aquaculture Center Publication No. 01002:769 pgs

Walia, S.S. and Kaur N. (2013). Integrated farming system- an ecofriendly approach for sustainable agriculturaleEnvironment - a review. Greener Journal of Agronomy, Forestry and Horticulture, 1(1): $001-011$

Wang, Y.H., Joobeur, T., Dean R.A. and Staub, J.E.(2007). Genome mapping and molecular breeding in cucurbits. In:Plant Breeding Reviews, 27: 213-244 